\title{
THE BEGINNINGS OF A MIXED SYSTEM OR, ADVOCATES AT THE CAPE DURING THE EARLY NINETEENTH CENTURY, 1828-1850
}

\section{HJ Erasmus*}

\section{Introduction}

In his study of the judgments of the Supreme Court of the Colony of the Cape of Good Hope during the second half of the nineteenth century, Reinhard Zimmermann stressed the importance, especially in a common-law procedural environment, of the role of the Bar. He pointed out that "[d]ie 'dogmatischen' Grundlagen des Urteilen hängen zu einem grossen Teil von der Quellenpräsentation durch die Advokaten ab". ${ }^{1}$

In this study, the focus shifts to the first half of the nineteenth century. The subject of that focus is the role of advocates during the first two decades (1828-1850) of the existence of the Supreme Court of the Colony of the Cape of Good Hope, which was established by the First Charter of Justice of 1827.

Under the provisions of the Charter, the advocates and judges operated within an environment in which a common-law judicial and procedural framework was

1 Reinhard Zimmermann "Die Rechtsprechung des Supreme Court of the Cape of Good Hope am Ende der sechziger Jahre des 19. Jahrhunderts" in J van der Westhuizen (ed) Huldigingsbundel Paul van Warmelo (Pretoria, 1984) 286-307 at 306. The role of advocacy in general was the subject of Jeremy Gauntlett SC's address at the Biennial Lecture of the Faculty of Advocates, Edinburgh, 20 Sep 2014: "Why advocacy matters - What matters in advocacy".

* Former Judge of the High Court of South Africa. Research Associate, Department of Private Law, University of Stellenbosch.

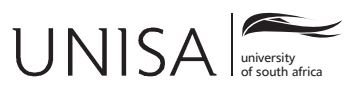


imposed upon the Roman-Dutch law that had been brought to the Cape by the Dutch settlers and confirmed by the Charter as part of the law of the Colony. The continued survival (to this day) of the Roman-Dutch law in that environment has on occasion been described as "remarkable".

It is customary to pay tribute to the efforts made by the judges (and in particular Menzies $\mathrm{J}^{3}$ ) during this early period to strengthen and build upon the foundations of Roman-Dutch law. Typical examples of such tributes are the following:

In certain areas it is possible to observe that the court continued to favour Roman-Dutch law strongly, but after Burton J's departure from the Cape real expertise lay with Menzies J and to a lesser extent with Wylde CJ and Kekewich J. Thus in provisional sentence cases the court almost without exception referred to Roman-Dutch sources ... ${ }^{4}$

There was always one judge to keep the lamp of Roman-Dutch learning alight. Shortly after the departure of Menzies came the native sons Cloete (1855-66) who had been a pupil of Van der Keessel, and the brilliant Watermeyer (1857-67), whose life, alas, was cut off in its flower. The future of Roman-Dutch law was assured. ${ }^{5}$

Ian Farlam has pointed out that while such tributes are justified, credit should be given to the advocates, learned and steeped in Roman-Dutch law, who were an important determinant of the character of the newly created Court. During these early years, the advocates gave the judges considerable assistance in their efforts to assure the future of Roman-Dutch law. ${ }^{6}$

A study of the professional activity of the advocates ${ }^{7}$ at the Cape during the early nineteenth century not only reveals their important role in the application

2 See Rena van den Bergh "The remarkable survival of Roman-Dutch law in nineteenth-century South Africa" (2012) 18(1) Fundamina 71-90.

3 Menzies was senior Puisne Judge of the Cape Supreme Court from 1827-1850. See C Graham Botha "The Honourable William Menzies 1795-1850" (1916) 33 SALJ 385-404; Stephen D Girvin "William Menzies of Edinburg. Judge at the Cape 1827-1850" (1993) Juridical Review 279-293.

4 Stephen D Girvin "The establishment of the Supreme Court of the Cape of Good Hope and its history under the Chief Justiceship of Sir John Wylde" (1992) 109 SALJ 291-306, 652-665 at 654.

5 HR Hahlo \& Ellison Kahn The Union of South Africa: The Development of its Laws and Constitution (Cape Town, 1960) at 208.

6 IG Farlam "The origin of the Cape Bar" (1988) 1 Consultus 36-39 at 39. Botha (n 3) at 401, in a single sentence gives some acknowledgment to the role of the advocates. P Spiller in his A History of the District and Supreme Courts of Natal 1846-1910 (Durban, 1986) emphasises (at 21) that an "important determinant of the administration of justice in Natal was the character of the Bar". The nineteenth century was not the first during which advocates had a vital role in the development of Roman-Dutch law. In his study of early Roman-Dutch law, JE Scholtens points out that as to its essential features, the Roman-Dutch law was in existence before the publication in 1631 of De Groot's Inleidinge, and that "it was the product of the labours of the advocates of the courts of Holland" ("Early Roman-Dutch law" (1959) Acta Juridica 74-83 at 83).

7 Though throughout the nineteenth century, most of the advocates at the Cape played a prominent part in public life, (CJ Brand, for example, was the first Speaker of the Cape Legislative Assembly; 
and development of the law. It also compels reconsideration of certain current assumptions.

\section{Advocates at the Cape before $1827^{8}$}

There are but few references in the early records of advocates practising at the Cape during the seventeenth and eighteenth centuries. ${ }^{9}$ In 1688, the Governor and Raad van Justitie admitted Jacob van Heurn to practise as an advocate and notary in all the courts at Cape Town and in the Court of Landdrost and Heemraden at Stellenbosch. The civil records of the latter court show that he frequently exercised this right. ${ }^{10} \mathrm{In}$ 1706, the name of Willem ten Damme appears as practising as an advocate. ${ }^{11}$ No professional qualification was required for admission as an attorney; it may be that, as in the Netherlands, an advocate had to be a doctor of laws. ${ }^{12}$

During the First British Occupation (1795-1803) changes were made to the administration of justice, ${ }^{13}$ but the position of legal practitioners was left unchanged.

In 1803, on the retrocession of the Cape to the Batavian Republic, CommissionerGeneral De Mist found that the administration of justice had fallen into a "sorry state" and proceeded to make wholesale reforms. ${ }^{14}$ The admission of legal practitioners was regulated: those seeking admission as attorneys had to pass an examination set by the court's commissioners, while advocates were expressly required to be graduates in law of a Dutch university. ${ }^{15}$

many advocates were elected to the Legislative Assembly and through the years their members regularly served as Attorney-General (Minister of Justice) and several as Prime Minister), the focus of this article is on their professional activity as practising lawyers in the first half of the nineteenth century. The advocates also played a vital role in the collection, editing and publication of the early law reports - see JP van Niekerk "An introduction to South African law reports and reporters, 1828 to 1910" (2013) 19(1) Fundamina 106-145.

8 On legal practitioners at the Cape during this period, see C Graham Botha "Early legal practitioners of the Cape Colony" (1924) 41 SALJ 255-262; PJ van der Merwe Regsinstellings en Reg aan die Kaap van 1806 tot 1834 (LLD, University of the Western Cape, 1984) at 34-36; GG Visagie Regspleging en Reg aan die Kaap van 1652 tot 1806 (Cape Town, 1969) at 49ff; L Wildenboer "The origin and division of the legal profession in South Africa: A brief overview" (2010) 16(2) Fundamina $199-225$ at $214-217$.

9 Botha (n 8) at 256.

10 Ibid.

11 Ibid; Visagie (n 8) at $49 \mathrm{n} 81$.

12 See Hahlo \& Kahn (n 5) at 202.

13 See Visagie (n 8) at 91-97.

14 For details of the reforms, see Hahlo \& Kahn (n 5) at 203-204; Van der Merwe (n 8) at 60-61; Visagie (n 8) at 98-113.

15 Art 130 of the Provisionele Instructie van den Raad van Justitie aan de Kaap de Goede Hoop (1803). See, further, Hahlo \& Kahn (n 5) at 203-204; Van der Merwe (n 8) at 60-61;Visagie (n 8) at 106-107. 
The Second British Occupation (1806) heralded a period of gradual and intermittent change in the administration of justice at the Cape, which culminated twenty years later in the fundamental changes introduced by the First Charter of Justice in $1827 .{ }^{16}$ During the period 1806 to 1827 the position of legal practitioners remained unaffected.

Advocates who practised at Cape Town ${ }^{17}$ prior to the promulgation of the First Charter of Justice in 1827 included Johannes Henoch Neethling, who later became a Judge of the old Court of Justice; ${ }^{18}$ Hendrik Cloete, who commenced practice at the Cape in 1816; ${ }^{19}$ Helperus Ritzema van Rijneveld; J Joubert; Christoffel Joseph Brand, who commenced practice in $1821 ;{ }^{20}$ Johannes de Wet, who commenced practice in $1823 ;{ }^{21}$ and $\mathrm{JH}$ Hofmeyr. In conformance with the requirements laid down by De Mist, they were all graduates of Dutch universities. ${ }^{22}$ Hendrik Cloete not only took his LLD at Leiden in 1811 under Van der Keessel, but was also called to the Bar by Lincoln's Inn on 24 April 1812. He later spent nearly ten years as a judge in Natal (1846-1855). In 1855, he returned to Cape Town where he served as third Puisne Judge for ten years (1855-1866).

The advocates had a sound knowledge of Roman-Dutch law and its sources. The records of cases decided before 1827 by the Appeal Court and the Council of Justice reflect extensive reliance on the authoritative writers on Roman-Dutch

16 Van der Merwe (n 8) at 64-237.

17 See Farlam (n 6) at 37; DV Cowen "The history of the Faculty of Law in the University of Cape Town 1859-1959. A chapter in the history of the survival of the Roman-Dutch law in South Africa" (1959) Acta Juridica 1-20 at 3 n 15.

18 On JH Neethling (1770-1838), see CR Kotzé sv "Neethling JH" Dictionary of South African Biography (hereafter DSAB) vol 4 (Durban, 1981) at 401.

19 On H Cloete (1792-1870), see JHDeV Cloete "Mr Justice Cloete" (1934) 51 SALJ 1-10; see, further, text to $n 57$ and 58 below.

20 On CJ Brand see HC Botha $s v$ "Brand, Sir Christoffel Joseph" in DSAB vol 2 (Cape Town, 1972) at 78 .

21 On J de Wet (1794-1875), see RFM Immelman $s v$ "De Wet, Johannes" in DSAB vol 1 (Cape Town, 1968) at 240. In 1804, he purchased the house in Strand Street, Cape Town, which is today the Koopmans-De Wet Museum; his daughter Maria Margaretha married Koopmans.

22 They were all graduates of Leiden University (Cowen (n 17) at 3 n 13). Eg, JH Neethling obtained his LLD in 1791; Hendrik Cloete took his LLD in 1811; CJ Brand took his LLD in 1820 on a thesis entitled Dissertatio politico-juridica de jure coloniarum; and J de Wet took his LLD in 1821 on a thesis De usucapione et praescriptione secundum principia juris Romani.

23 This is evident from the research project undertaken jointly by the University of the Western Cape, Potchefstroom University (now the North-West University) and Leiden University of the judgments in civil cases of the Court of Justice at the Cape during the period 1806-1827. The comprehensive final report (314 pages), issued in 1992, was never published. It is avalailable on the internet at http//dspace.nwu.ac.za/bitstream/handle/1039 under the title Die Kaapse Regspraak-Projek: Die Siviele Appèlhof en die Raad van Justisie, Hofstukke en Uitsprake wat betrekking het op Siviele Sake 1806-1827: 'n Evaluering van Capita Selecta uit bepaalde Gebiede van die Reg aan die Kaap. See also the studies of Van der Merwe (n 8) at 208-221, and GG Visagie "The law applied at the Cape from 1652 to 1829 " in IMI Koster-Van Dijk \& A Wijffels 
law. ${ }^{23}$ Their books were readily available - in the second half of the eighteenth century there was no shortage of law books at the Cape. ${ }^{24}$ The list of authorities referred to in the cases is indeed comprehensive: Johannes Voet Commentarius ad pandectas; Simon van Leeuwen Het Roomsch Hollandsch recht, Censura forensis, Manier van procedeeren in civile en criminele zaken; Joannes van der Linden Rechtsgeleerd practicaal, koopman's handboek, Manier van procederen; Simon van Groenewegen van der Made Tractatus de legibus abrogatis et inusitatis; Merula Manier van procederen. There is also extensive reference to the works on criminal law of Antonius Matthaeus II, ${ }^{25}$ Benedictus Carpzovius ${ }^{26}$ and JM Barels. ${ }^{27}$ Some of the other authorities relied upon were Damhouder, Peckius, Wassenaar, Gail, Faber, Loenius, Schrasset, Schomaker Pothier, Moorman, Vromans, Zurck and Leyser.

\section{Advocates at the Cape 1828 to 1850}

In the Charter of Justice of 1827, the Supreme Court was given control over the admission and suspension of legal practitioners. ${ }^{28}$ The requirement that advocates have been admitted to a United Kingdom Bar or were doctors of law of Oxford, Cambridge or Dublin ${ }^{29}$ has given rise to a persistent misconception that from the outset the survival of Roman-Dutch law was under threat, if not from a hostile Bar, at least from one with little knowledge of Roman-Dutch Law. Thus "the requirement that barristers be trained in Britain" is listed as one of the factors that strengthened the tendency towards an admixture of English and Roman-Dutch law. ${ }^{30}$

(eds) Miscellannea forensia historica: ter gelegenheid van het afscheid van Prof Mr J de Smidt (Amsterdam, 1988) 325-343 at 334-337.

24 See Wouter de Vos Regsgeskiedenis (Cape Town, 1992) at 236. See, further, Appendix II and Appendix III in Visagie (n 8); C Graham Botha "An 18th century law library" (1935) 52 SALJ 169-182. In 1998, J Th de Smidt published a catalogue of the law books of the Raad van Justitie (now in the library of the High Court in Cape Town) and the Van Dessin Collection (now in the South African Library in Cape Town): Old Law Books from the Libraries of the 'Raad van Justitie' (High Court) and JN van Dessin (South African Library) (Leiden, 1998). Advocate J de Wet had a very extensive library - see RFM Immelman $s v$ "De Wet, Johannes" in DSAB vol 1 (n 21) at 240.

25 De criminibus.

26 Practica nova imperialis Saxonica rerum criminalium and D van Hogendorp's translation under the title Verhandeling der lijfstraffelijke misdaaden.

27 Criminele advysen.

28 Sections $17-23$ of the Charter of Justice.

29 Section 17 of the Charter of Justice provides: "And we do hereby authorise and empower the said Supreme Court of the Colony of Cape of Good Hope to approve, admit, and enrol such persons as shall have been admitted as Barristers in England or Ireland or Advocates in the Court of Sessions of Scotland, or to the Degree of Doctor of Laws at Our Universities of Oxford, Cambridge, or Dublin to act as Barristers or Advocates in our said Supreme Court."

30 Eduard Fagan "Roman-Dutch law in its South African historical context" in Reinhard Zimmermann \& Daniel Visser (eds) Southern Cross. Civil Law and Common Law in South Africa (Oxford, 1996) 33-64 at 57. See, also, Van den Bergh (n 2) at 84-86. 
However, the Charter of Justice also made provision for the admission of those who had practised as advocates in the former Court of Justice ${ }^{31}$ - who from 1803 had to have graduated in law in Holland. ${ }^{32}$

At the first sitting of the newly established Supreme Court of the Colony of the Cape of Good Hope, nine advocates were admitted under the new regime introduced by the Charter of Justice of $1827 .{ }^{33}$ Seven of them had been advocates of the former Court of Justice; namely, JH Neethling, H Cloete, HR van Rijneveld, J Joubert, CJ Brand, J de Wet and JH Hofmeyr. Also admitted were D Denijssen, ${ }^{34}$ the former Fiscal whose office had been replaced by that of the Attorney-General (the first incumbent being Anthony Oliphant ${ }^{35}$ ) and Saxe Bannister, the first English-born advocate to be a member of the Cape Bar. Bannister practised at the Cape Bar for only a brief period, until July 1829. Subsequently, on 28 February 1828 and 27 March 1828 respectively, two other advocates of the old court, OM Bergh and A Faure, ${ }^{36}$ were also admitted. The next three advocates to be admitted were also colonial born: JG Stadler (admitted 31 Dec 1832), FL Stol (admitted 28 Feb 1833), and W Hidding (admitted 12 Jul 1833). ${ }^{37}$ This means that with the exception of the Attorney-General and Saxe Bannister, all persons admitted as advocates of the Cape Supreme Court

31 Section 18 of the Charter of Justice provides: "And we further authorise and empower the said Supreme Court to admit any persons to practise as barristers or advocates therein, who previously to the promulgation of these presents within the said Colony, have been admitted to practise as advocates in the Supreme Court of Justice heretofore existing within the same." Neither Fagan (n 30) nor Hahlo \& Kahn (n 5) nor Van den Bergh (n 2) nor Cowen (n 17) make mention of the fact that the Charter made provision for the admission of those who had practised in the former Court of Justice.

32 See n 15 above. It was only in 1858 that Acts 4 and 12 of 1858 (Cape), which set up a Board of Public Examiners, made provision for the admission of advocates who had qualified in South Africa; see, further, Cowen (n 17) at 7-11.

33 Farlam (n 6) at 37-39; and see Botha (n 3) at 391.

34 On D Denijssen, see CR Kotzé sv "Denijssen, Daniel" in DSAB vol 3 (Cape Town, 1977) at 207. He also held an LLD from Leiden University.

35 On Anthony Oliphant, see FG Richings $s v$ "Oliphant, Sir Anthony" idem at 662. He was admitted as an advocate in Edinburgh and called to the Bar at Gray's Inn on 26 May 1827 and the King's Inn in Dublin in 1829. Before coming to the Cape, he practised at the Irish Bar.

36 The only reference to him I was able to trace is one in the rubric dealing with his cousin, also A Faure (1795-1875) in HB Giliomee $s v$ "Faure, Antonij Alexander" in DSAB vol 2 (n 20) at 234 in which he is described as a doctor of laws and an advocate.

37 Hidding's father, also W Hidding, was a Judge of the Court of Justice on which he served from 1803 to 1827 . Hidding Jnr (1808-1899) obtained an LLD at Groningen University and qualified as an advocate in Edinburgh. He practised regularly on the Circuit Court; see JC Visagie sv "Hidding, Willem" in DSAB vol 3 (n 34) at 300. He was present and acted as interpreter on 22 Oct 1842 at Allemans Drift when Menzies J took possession, in the name of the Queen, of all territory east of 22 degrees longitude and 25 degrees south latitude not being the possession of the Portuguese Crown or any native tribe or chief. Sir George Napier, Governor at the Cape, did not approve of Menzies' proclamation, and by a proclamation dated 3 Nov 1842 repudiated the whole proceeding as being unauthorised (see Botha (n 3) at 396-397). 
in the first ten years of its existence were colonial born. The advocates whose names appear in the Menzies' Reports ${ }^{38}$ as having been actively involved in litigation in the Cape Supreme Court were all graduates of Dutch universities and former advocates of the old Court of Justice, the one exception being the Attorney-General. The idea that the "fair number of colonists who obtained degrees from distinguished universities in the Netherlands" was a phenomenon of the late nineteenth century only ${ }^{39}$ is therefore not borne out by the facts.

On 30 December 1836, William Musgrave became the second English-born advocate ${ }^{40}$ to be admitted at the Cape. ${ }^{41}$ Musgrave soon acquired a reputation as an able lawyer and established a sound practice. Seven years later, in 1843, he was elevated to the Bench upon the retirement of Kekewich J.42

On 12 July 1837, Petrus Johannes Denijssen was admitted. He was the son of D Denijssen, the former Fiscal who had been one of those admitted in 1827. PJ Denijssen obtained an LLD from Leiden University, subsequently entered the Inner Temple and was called to the Bar in London on 18 November 1836. He was elevated to the Bench in 1868 and remained a Judge of the Cape Supreme Court until 1877.43

On 31 May 1839 followed the admission of JF and JH Dreyer. ${ }^{44}$ On 26 November 1839, JW Ebden was admitted. He was born at the Cape, was a graduate of Cambridge, and on 28 May 1835 was called to the Bar by the Middle Temple. Oliphant retired as Attorney-General in March 1839, to be succeeded briefly by

38 On the Menzies' Reports, see $\mathrm{n} 48$ below.

39 As Van den Bergh (n 2) at 86 seems to suggest when she refers, by way of example, to Judges Juta, Kotzé, the De Villiers brothers, Wessels, Steyn and Hertzog.

40 Saxe Bannister was the first, but he practised at the Cape Bar for but a few months.

41 The admission of Musgrave gave rise to an extraordinary attack on the Cape Bar in an editorial published in the issue of 31 Jan 1837 of The Moderator, a local newspaper. Three causes were identified "which justify our predilections in favour of English Barristers. The first is, the character and manner of their education; secondly, the class of person who betake themselves to the profession; and thirdly, the manner in which the legal business is conducted." De Zuid-Afrikaan, with a number of advocates (including CJ Brand, JH Neethling and J de Wet) on its editorial board, sprang to the defence of the Cape Bar in an article reprinted in an English translation in the 28 Feb 1837 issue of The Moderator. As Farlam points out (n 6), the writer had no difficulty in demolishing the three "causes" for preferring English barristers: the advocates were all doctors of law from leading universities in Holland; they came from the leading families in the Colony, and the Supreme Court had been functioning for ten years in a vastly superior manner to that of the old Court of Justice.

42 See F St L S "The Hon Mr Justice William Musgrave" (1937) 54 SALJ 279-291 at 288.

43 See JC Quinton $s v$ "Denyssen, Petrus Johannes" in DSAB vol 5 (Pretoria, 1987) at 185; Anon "The late Hon Petrus J Denyssen" (1903) 20 SALJ at 221-223.

44 I have been unable to find any information about them except that the name of Dreyer is mentioned as one of the signatories of an address presented by the advocates at the Cape to Bell CJ upon his retirement (see Stephen D Girvin "The architects of the mixed legal system" in Zimmermann \& Visser (n 30) 95-139 at $105 \mathrm{n}$ 58). There is no mention in the Menzies' Reports of any appearance as advocates before the Cape Supreme Court. 
Musgrave, who was in turn, in September 1839, succeeded by William Porter. ${ }^{45}$ The redoubtable Irishman, who remained Attorney-General for twenty-seven years until March 1866, was destined to dominate legal practice and indeed public life at the Cape in a manner that has perhaps not received sufficient recognition. ${ }^{46}$ In 1847 the brilliant EB Watermeyer was admitted; he was South-African born, and educated in Holland where he obtained an LLD at Leiden University. Before his return to the Cape he was in 1847 called to the Bar by the Inner Temple in London. ${ }^{47}$

Perusal of the Menzies' Reports, ${ }^{48}$ which cover the years 1828 to 1849 , reveals that practice before the Cape Supreme Court was during that time dominated by CJ Brand and $\mathrm{H}$ Cloete, both consummate masters of Roman-Dutch law. ${ }^{49}$ There were also regular appearances by the two Denijsens, J de Wet, JH Hofmeyr and J Joubert. ${ }^{50}$ After 1837, the names of William Porter, Musgrave and Ebden appear regularly, and after 1847 that of Watermeyer begins to appear. From all the foregoing it follows that during the period 1827 to 1850 , apart from the Attorney-General, only one English-born advocate (Musgrave) practised at the Cape, and that only one of the South African-born advocates (Ebden) was not a graduate of a Dutch university. Several of those who were graduates of a Dutch university had also been called to the Bar in London.

Perusal of the Menzies'Reports further reveals the extent to which the advocates relied on Roman-Dutch authority. ${ }^{51}$ In every contested civil case Roman and RomanDutch authority are cited; sometimes on an extensive scale as in, for example, In re Insolvent Estate of Loudon, Discount Bank v Dawes ${ }^{52}$ and Harris v Trustee of Buisinne..$^{53}$ The range of authority cited is comprehensive: from $\mathrm{A}$ to $\mathrm{Z}$ as it were -

45 On William Porter, see JL McCracken $s v$ "Porter, William" in DSAB vol 1 (n 21) at 623. He was born in Ireland and called to the Bar by King's Inn in Dublin. He practised at the Irish Bar before coming to Cape Town.

46 See JL McCracken New Light at the Cape of Good Hope. William Porter. The Father of Cape Liberalism (Belfast, 1993).

47 See F St L S "Mr Justice EB Watermeyer" (1935) 52 SALJ 135-142 at 137.

48 The Menzies' Reports were compiled and edited from the manuscripts of Menzies J by James Buchanan (later Buchanan J) and published in 1870. Some of the notes are so short as to be cryptic; others are comprehensive with a full reproduction of counsels' arguments and citations of authority. The reports are a reliable indication of the nature and state of practice before the Cape Supreme Court at the time. On the Menzies'Reports, see Stephen D Girvin "Law reporting: Menzies' Reports, precedent and legal sources at the Cape Colony in the nineteenth century" (1995) 63 Tijdschrift voor rechtsgeschiedenis at 103-118; Girvin (n 4) at 654; Van Niekerk (n 7) at $111-113$.

49 See, further, the text to nn 57 and 58. Botha (n 3) at 401 gives recognition to the important role that Brand and Cloete played in this regard.

50 The Menzies' Reports reflect the odd appearance by Stadler (Blore v Dreyer (1833) 1 Menz 128) and Hidding (Board v De Villiers (1840) 2 Menz 55).

51 See Girvin (n 48) at 110-112.

52 (1829) 1 Menz 380.

53 (1840) 2 Menz 105. 
from Arntzenius to Zutphen $!^{54}$ The links of the advocates with the preceding regime are reflected in the occasional citation as authority, especially in the early years, of decisions of the former Court of Justice.$^{55}$ It should be kept in mind that prior to 1828 these advocates practised within a judicial regime in which Roman-Dutch law was still a living system of law within Holland.

The contention that the advocates who practised at the Cape in the early nineteenth century had limited knowledge of the Roman-Dutch sources cannot be sustained. ${ }^{56}$ They were all law graduates of Dutch universities, and outstanding amongst them were CJ Brand and Hendrik Cloete. Cloete spent ten years in practice before the Court of Justice (1816-1827) and almost twenty years (1828-1846) in practice at the Cape Bar. As a Judge, Cloete was highly regarded for his comprehensive knowledge of the Roman-Dutch authorities, ${ }^{57}$ and his erudite application of Roman-Dutch law played an important role in keeping it alive in Natal. ${ }^{58}$ His sterling work as advocate during the first two decades of the Cape Supreme Court has gone unheralded.

The superimposition of a common-law judicial and procedural framework upon the Roman-Dutch law profoundly influenced the manner of practice at the Cape. On questions of substantive law, the advocates referred extensively to writers on Roman-Dutch law. On questions of practice and procedure, they referred to English works. In Rogerson v Meyer \& Berning ${ }^{59}$ counsel and the Court referred to texts from Justinian's Code, numerous passages from Voet, Leeuwen's Censura forensis, Van der Linden's Koopman's handboek and Pothier's Traité des obligations. In the same case, on questions of procedure, reference was made to Harrison's Digest, Tidd on Practice, Chitty on Pleading, Archbold on Pleading, Maddox on Chancery Practice, and Stephen on Pleading. All these works deal with common-law practice prior to the abolition of the forms of action. No wonder that traces of the forms of action are found in nineteenth-century South African cases. ${ }^{60}$

54 The range of authorities cited include the Corpus iuris civilis, the Placaat boeken, the Hollandsche consultatien, and the works of Arntzenius, Bort, Brissonius, Brouwer, Brunneman, Bynkershoek, Carpzovius, Cos, Domat, Groenewegen, Grotius, Huber, Leeuwen, Leyser, Loenius, Lybrechts, Lyzenius, Matthaeus, Merula, Neostadius, Pothier, Schulting, Van der Keessel, Van der Linden, Vinnius, Voet, Zangerus, Zurck and Zutphen. On the citation of Roman-Dutch authority as reflected in the Menzies' Reports: see Girvin (n 48).

55 Eg, Witham $v$ Venables (1828) 3 Menz 291; Joosten $v$ Grobbelaar (1832) 1 Menz 149; Reeves $v$ Reeves (1832) 1 Menz 244 at 248; Koemans v Van der Watt (1838) 1 Menz 36. See Girvin (n 48) at 108 .

56 Girvin (n 48) at 113 states that "we may very well admire the attempts by the early Cape lawyers to do justice to the received principles of the Roman-Dutch law when they had limited knowledge of the basic sources".

57 Girvin (n 44) at 101.

58 Spiller (n 6) at $24 \mathrm{f}$.

59 (1837) 2 Menz 38.

60 See HJ Erasmus "The interaction of substantive law and procedure" in Zimmermann \& Visser (n 30 above) 141-161 at 152-155. See, also, HJ Erasmus "The interaction of substantive and procedural law: The Southern African experience in historical and comparative perspective" (1990) 1 Stellenbosch LR 348-371. 
The picture would not be complete without mention of the fact that in certain areas of the law, the advocates did not hesitate to cite English authority. ${ }^{61} \mathrm{~A}$ few examples will suffice. On bills of exchange there is reference to, among others, Chitty on Bills, Bayley on Bills, Byles on Bills, Story on Bills; on the law of insolvency there is reference to Bell's Commentaries on Bankrupt Law, Bell on Bankruptcy, Cooke's Bankrupt Law and Judge Burton's treatise on Insolvent Law; ${ }^{62}$ on shipping there is reference to Abbott on Shipping, Nott on Shipping and Lawes on Charterparties. There is also reference to general works such as Blackstone's Commentaries, Burge's Commentaries on Colonial and Foreign Laws and Smith's Compendium of Mercantile Law.

The influence of the citation of old authority is apparent from the judgments of the Cape Supreme Court, and is confirmed by express statements such as the following in Witham $v$ Venables: ${ }^{63}$

But the Court, after full argument and a deliberate consideration of all the authorities, held ...

The authorities referred to by the plaintiff and the defendant included works of Van der Linden, Huber, Leeuwen, numerous passages from Voet, Brissonius and Paulus Merula. The defendant also referred to two judgments of "the late Court" which were handed down on 6 April 1822 and 29 April 1824.

\section{The case of Letterstedt $v$ Morgan}

In 1849 at the end of the period under review, in Letterstedt $v$ Morgan and Others ${ }^{64}$ Wylde CJ made a statement that on the face of it seems to gainsay the views expressed thus far. The statement has given rise to the view that the "Roman-Dutch authorities held but a tenuous position in the early years of the Supreme Court," ${ }^{95}$ and that Wylde "was no great defender of Roman-Dutch law" authorities cited by counsel. The statement reads as follows:

Quote what Dutch or Roman books you please - musty or otherwise ${ }^{67}$ - and they must be musty if they lay down such doctrines. I belong to a higher Court than they refer to -

61 Girvin (n 4) at 654; Girvin (n 48) at 113.

62 The full title is Observations on the Insolvent Law of the Colony of the Cape of Good Hope.

63 (1828) 1 Menz 291. The report is in narrative form and does not give the actual wording of the judgment that was handed down.

64 (1849) 5 Searle 373 at 381.

65 Fagan (n 30) at 56.

66 Girvin (n 44) at 97.

67 The reference to "musty" authority probably derives from Porter who in his address to the Court used the phrase "musty volumes", which elicited the following comment from Musgrave J (at 377): "But the Attorney-General will not deny that these musty volumes, when it suits his purpose, are very often obtruded on the attention of the Court and applied to cases which he brings forward. Then again, by the terms of the Charter, 
a Court not to be broken up or paralysed by their authority, much less by the maxims of philosophers dozing over the midnight lamp in their solitary chambers. My Queen has sent me here to administer Justice under the Royal Charter; and the practice of the Courts of Flanders, Batavia or Trinidad, are no authority to me ... [W] hen you speak of the Institutions of Holland, and of bonding myself down to the practice of Dutch courts - I absolve myself from that bondage, I look to my Charter, to my oath and to my duty.

The case arose from the violent agitation against the establishment of a penal colony at the Cape ${ }^{68}$ during which Wylde CJ and Menzies J had advised the government extra judicially. ${ }^{69}$ When Letterstedt (represented by Porter and Ebden) brought a claim for damages arising from the situation, the defendants (represented by CJ Brand, JH Brand $^{70}$ and EB Watermeyer) raised an exceptio iudicis suspecti and called for the recusal of the judges (Wylde, Menzies and Musgrave).

One should not lose sight of the fact that the issue before the Court was a narrow one: The recusal of the judges. ${ }^{71}$ Referring to a host of civil-law authority, ${ }^{72}$ counsel for the defendants contended that the judges could not participate in the question of

we are told that we are not bound to decide simply upon the Ordinances, but according to the laws in force, and there is no doubt that the Dutch law is in force in this Colony, except in so far as it has been abrogated by subsequent enactments."

68 See, in general, AF Hattersley The Convict Crisis and the Growth of Unity; Resistance to Transportation in South Africa and Australia, 1848-1853 (Pietermaritzburg, 1965).

69 The background to the case is described by Girvin (n 4) at 656 . The vitriolic exchanges that characterised the hearing are set out by F St L S (n 42) at 288-291.

$70 \mathrm{JH}$ Brand, the son of CJ Brand, was a graduate (LLD) of Leiden University and was called to the Bar in London (see MCE van Schoor sv "Brand, Johannes Henricus" in DSAB vol 1 (n 21) at 110. He was in 1859 appointed the first professor of law at the South African College (predecessor of the University of Cape Town): Cowen (n 17) at 7-11. He was President of the Orange Free State from 1863 to 1888 .

71 The Roman-Dutch law on recusal is considered by "Karroo" in a note entitled "Recusation" in (1924) 51 SALJ 33-37.

72 Among the many authorities he cited, CJ Brand referred to the Dissertatio de recusatione iudicis of Antonius Schultingius, first published in Franeker in 1708. The full title is Dissertationes. De recusatione iudicis. Pro rescriptis Imperatorum Romanum: de transactione super controversiis, quae ex ultimis voluntatibus profiscuntur, etiam non inspectis vel cognitis illarum verbis recte ineunda. Schulting in 1713 succeeded Voet as professor at Leiden. In the Stellenbosch University Library there are two copies of the Dissertatio, one of the Franeker edition of 1708 and one of the later (1714) Leiden edition. Brand also referred to the Tractatus de exceptionibus (Becker, 1598) of the German jurist Joannes Zangerus who was professor at Wittenberg. AA Roberts $A$ South African Legal Bibliography (Pretoria, 1942) was unable to trace a copy of the work in South Africa. As far as I am aware there is a copy in the Merensky Library at Pretoria University of the 1620 edition printed at Frankfurt under the title Tractatus duo: unus de exceptionibus, alter de quaestionibus, seu, torturis reorum. There is also a copy under the same title in the library of the University of South Africa of an edition printed in 1730 (Conrad). 
their own recusation - judges when challenged should at once retire. ${ }^{73}$ The further contention was that if recusal of the whole court and not an individual judge was sought, the issue of recusal must be decided by a superior court or the sovereign. ${ }^{74}$ It was especially this latter contention that aroused the ire of Wylde CJ and led to his extraordinary outburst; for, if the judges were to be recused, the Court would be left in limbo without a quorum. Hence his statement that his Court could not be "broken up or paralysed" by such authority, and that he could not be bound by the practice (my emphasis) of the Dutch courts. Indeed, he stated that the Dutch practice as described by Voet could not be applied to the situation at the Cape: ${ }^{75}$

When we look at Voet, we find that there was a court of seven, of five, and so on. Can we look at their practice to regulate our procedure in such courts as this?

Menzies $\mathrm{J}$ in his judgement considered the civil law authorities and stated his conclusion as follows: ${ }^{76}$

It is a fixed rule of law that an exception cannot be taken to the whole Court or to a quorum; and an exception that would have the effect of destroying a legal quorum cannot be pleaded. On that ground, and on that ground alone, I stated that, notwithstanding what had been brought to my notice, it was my duty to remain.

This conclusion finds support in Kersteman's Hollandsch rechtsgeleerd woorden$b_{o e k} k^{77}$ in which it is said that the challenging or recusing of a whole court has been abolished, though recusation can still take place against the particular person of a judge.

It can hardly be contended, on the strength of Chief Justice Wylde's statement, that the Roman-Dutch authorities "held but a tenuous position in the early years of the Supreme Court". ${ }^{78}$ If the position was indeed tenuous, one would not expect counsel to have referred in extenso to civil-law authority (as they had done for the

73 The principle is stated thus by Schultingius in his Dissertatio de recusatione iudicis cap XII §8: "Hodie si quis ex collegis judicum recusetur, moris est, ut ab aliis ejusdem collegii membris recusandi causa examinetur, ac de ea pronuncietur. Ipse recusatus ut de illa hoc est, de propria causa cognoscat, nulla pacto permittetur."

74 Amongst a host of other authority, Voet 5147 was cited in support of this proposition. Both Wylde CJ and Menzies J refer to this passage in their judgments.

75 At 381.

76 At 388. See, also, at 393 where Menzies J states: "The decision is that with regard to the alleged opinions the exception is wrong in point of fact; secondly, that it has not pleaded the exceptio iudicis suspecti; and thirdly, that although it is possible that some fact might exist, yet it is so vaguely and inartificially pleaded that on that ground also the exception is out of Court."

772 ed (Amsterdam, 1777) at 406 sv "recusatio".

78 See $\mathrm{n} 64$ above. 
preceding twenty years). Moreover, in his judgment, Musgrave J explicitly confirmed that "there is no doubt that the Dutch law is in force in this Colony". ${ }^{79}$ Menzies J in his judgment considered the civil-law authorities and based his decision not to withdraw on their authority. Even Wylde CJ gave different circumstances as reason for not following Voet.

After all, at the time of the Letterstedt-case, Wylde CJ had for twenty-two years presided over a court in which Roman and Roman-Dutch authority had from the outset been extensively quoted and followed. Thus in In re Insolvent Estate of Buisinne; Van der Byl and Meyer $v$ Sequestrator and Attorney-General, ${ }^{80}$ a case that came before the Cape Supreme Court in the first year of its existence, it is stated that "the Court is of opinion that these authorities [Codex, Pothier, Leeuwen, Voet, Van der Keessel] prove, that, the law of Rome and Holland, and, consequently, of this colony ....". 81

In his judgment in a case decided not long after Letterstedt, in 1851, Wylde CJ was not averse to accepting Roman-Dutch authority when he said that the "action for slander is given in the Roman-Dutch law in case of words uttered dolo malo for the purpose of traducing the character and estimation of another". ${ }^{82}$ In Pike v Hamilton, Ross \& $\mathrm{Co}^{83}$ one of Wylde's last cases before his final illness, counsel on both sides (Watermeyer and Porter AG for the plaintiff, and CJ Brand for the defendant) referred to the Institutes, Pothier and a number of passages from Voet and Grotius. The three judges agreed that the law as set out in the authorities cited by counsel was applicable to the case before them. Wylde, who had lost his notes and gave judgement from memory, simply stated that the position was as set out by Voet, Leeuwen and "all the authorities". ${ }^{84}$ In their concurring judgments, Judges Ebden and Bell explicitly based their judgments on the authorities cited by counsel in argument.

\section{Conclusion}

The year 1850, when Menzies J died after serving as senior Puisne Judge for twentythree years from 1828 to 1850 , marks the end of an era in the early history of the Cape Supreme Court.

The first two decades of its existence constitutes perhaps the most important formative period in the history of the Cape Supreme Court. Form and content had

79 See the text at $\mathrm{n} 66$ above.

$80 \quad$ (1828) 1 Menz 318.

81 Idem at 327.

82 White $v$ Pilkington (1851) 1 Searle 107 at 119.

83 (1855) 2 Searle 191.

84 The statement by Girvin (n 4) at 66 that Wylde CJ "delivered an impressive judgment citing a variety of Roman-Dutch authorities" is perhaps a somewhat favourable exaggeration. 
to be found for the system created by the Charters of Justice: A system whose main formative element, Roman-Dutch law, had to find application within a judicial and procedural framework of common-law origin. The advocates who practised at the Supreme Court during those years were eminently qualified and experienced to fulfil that task. Most of them were graduates of Dutch universities and, equally importantly, most of them had practised during the previous regime when the Roman-Dutch law was still a living system in Holland, the then governing colonial power. Moreover, they were also familiar with English law and practice, several of them having been called to the Bar in London or Edinburgh. From the outset, it was these advocates who were a most important determinant factor in shaping the character of the newly created Court.

At the Cape during that time there was no confrontation between the proponents of Roman-Dutch law and English law - the bellum juridicum is a twentieth-century phenomenon. Roman-Dutch law continued to be accepted as part of the law of the land in the practice of the Cape Supreme Court throughout the nineteenth century. This acceptance was emphatically confirmed during the forty years that Lord De Villiers dominated the scene as Chief Justice. As a member of the Privy Council he wanted all cases in which Roman-Dutch law featured to be allocated to him on the ground that the other members of the Privy Council had an inadequate knowledge of Roman-Dutch law. ${ }^{85}$

This does not mean that Roman-Dutch law was the only actor on the stage. Not only had ties with its country of origin been severed, but the introduction in Holland of a civil code based on the French Civil Code meant that Roman-Dutch law was no longer a living system. Roman-Dutch law at the Cape then found application within an English-colonial political environment, and the courts operated within a procedural regime of English origin. In the circumstances, because the law needed to keep pace with the rapid economic developments of the second half of the nineteenth century, the courts turned to English law to complement Roman-Dutch law (especially in the field of mercantile law) and legislation was based on English precedents. ${ }^{86}$ Whatever tensions there might have been between them at times, these various elements were the building blocks of the new mixed system. ${ }^{87}$ And from the very first years of the life of the Cape Supreme Court, the advocates in a pragmatic way set about fashioning a coherent system from these building blocks. They laid the foundations of the system that during the nineteenth and early twentieth centuries spread to the rest of Southern Africa, the system that underlay the law of the Union

85 See Eric A Walker Lord De Villiers and his Times. South Africa 1842-1914 (London, 1924) at 287. His request was not granted.

86 Fagan (n 30) at 57.

87 The interplay of civil law and common law is set out by Zimmermann (n 1) and Van den Bergh (n 2). 
of South Africa of 1910 and underlies the law of the Republic of South Africa of today. ${ }^{88}$

\section{ABSTRACT}

In his study of the judgments of the Supreme Court of the Colony of Good Hope during the late nineteenth century, Reinhard Zimmermann stressed the importance of the role of the Bar. A study of the professional activity of the advocates at the Cape Bar during the early nineteenth century necessitates reconsideration of current assumptions. The Charter of Justice of 1827 required advocates to have been admitted to a United Kingdom Bar or to be doctors of law of Oxford, Cambridge or Dublin. This gave rise to the misconception that from the outset the survival of RomanDutch law was under threat, if not from a hostile Bar, at least from one with little knowledge of Roman-Dutch Law. The Charter of Justice also made provision for the admission of persons who had practised as advocates in the former Court of Justice and from 1803, were required to have graduated in law in Holland. For the first ten years of its existence, only former advocates of the old Court of Justice practised before the Cape Supreme Court, the one exception being the Attorney-General. Perusal of the Menzies' Reports, which cover the years 1828 to 1849 , reveals the extent to which advocates relied on Roman-Dutch authority. In every contested civil case old authority is cited, sometimes on an extensive scale. During the first years of the Cape Supreme Court, the advocates played a vital role in affirming the status of Roman-Dutch law as an integral part of the law of the Colony. This continued throughout the nineteenth century. At the Cape during the nineteenth century there was no bellum juridicum between the proponents of Roman-Dutch law and English law. This does not mean that Roman-Dutch law was the only actor on the stage. Ties with Holland had been severed. Roman Dutch-law found application within an English colonial political environment, and the courts operated within a procedural regime of English origin. In the Netherlands, the country of origin of Roman-Dutch law, the introduction of a code based on the French Civil Code meant that RomanDutch law was no longer a living system. In the circumstances, developments in the field of mercantile law, in particular, were assimilated with reference to English law and through legislation derived from English precedents. Whatever tensions there might have been at times, these various elements were in fact the building blocks of the new mixed system. From the very first years, the advocates, in a pragmatic way, played their part in fashioning a coherent system from these building blocks.

88 The current system is set out by CG van der Merwe et al "The Republic of South Africa" in VV Palmer (ed) Mixed Jurisdictions Worldwide. The Third Legal Family (Cambridge, 2012) 95-215. 